\title{
Characterization and comparative nutritional study of three strains of Kinnow Mandarin (Citrus reticulata Blanco)
}

\author{
Muhammad Nawaz Khan', Muhammad Asim¹ ${ }^{*}$, Abid Mahmood², Ehsan-ul-Haq1, Tehseen Ashraf ${ }^{3}$, \\ Naveeda Anjum4 , Faisal Hayat ${ }^{5}$, Raza Salik¹, Abdullah Jamil1, Rafi Qamar6* \\ ${ }^{1}$ Citrus Research Institute, Sargodha, Pakistan \\ ${ }^{2}$ Ayub Agricultural Research Institute, Faisalabad, Pakistan \\ ${ }^{3}$ Department of Horticulture, College of Agriculture, University of Sargodha, Pakistan \\ ${ }^{4}$ Barani Agriculture Research Institute, Chakwal, Pakistan \\ ${ }^{5}$ Key Laboratory of Biology and Genetic Improvement of Horticultural (Nutrition and Physiology) in the Ministry of \\ Agriculture, China Agricultural University, Beijing, 100193, China \\ ${ }^{6}$ Department of Agronomy, College of Agriculture, University of Sargodha, Pakistan
}

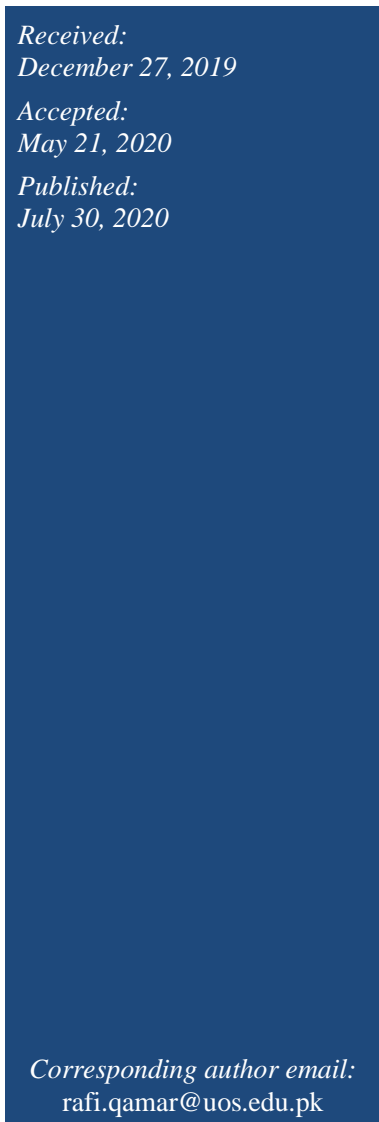

\begin{abstract}
The high number of seeds per fruit is a major hindrance in export, fresh fruit consumption as well as in the processing industry. A seedless trait in Kinnow is the utmost desirable characteristic to accelerate the local and export markets. In this comparative study, three strains of Kinnow (normal seeded Kinnow, low seeded and seedless Kinnow) grafted on Rough Lemon rootstock were evaluated for various physico-chemical attributes and nutritional parameters at gene pool center of Citrus Research Institute, Sargodha, Pakistan. Even though conventionally used normal seeded Kinnow performed better in various aspects like fruit size, firmness, acidity, and vitamin $\mathrm{C}$ contents. Two new strains of Kinnow mandarin delineate promising nutritional value regarding various physicochemical and proximate analysis parameters like TSS, total sugars, Beta carotene, fat, and ash percentage $(11.95 \%$, $7.84 \%, 63.92 \mathrm{~g} / 100 \mathrm{ml}$, and $2.03 \%$ respectively). Seedless Kinnow and low seeded Kinnow strains portray similar results in various citrus quality and nutritional value aspects, anticipating a healthier and progressive domestic and export market.
\end{abstract}

Keywords: Citrus, Seedless, Vitamin-C, Physio-chemical attributes, Proximate analysis, Fruit quality

\section{How to cite this:}

Khan MN, Asim M, Mehmood A, Haq EU, Ashraf T, Anjum N, Hayat F, Salik R, Jamil A, and Qamar R, 2020. Characterization and comparative nutritional study of three strains of Kinnow Mandarin (Citrus reticulata Blanco). Asian J. Agric. Biol. 8(3): 299-307. DOI: https://doi.org/10.35495/ajab.2019.12.570

This is an Open Access article distributed under the terms of the Creative Commons Attribution 3.0 License. (https://creativecommons.org/licenses/by/3.0), which permits unrestricted use, distribution, and reproduction in any medium, provided the original work is properly cited.

\section{Introduction}

Citrus is considered one of the major fruit crops cultivated in several tropical or subtropical climates
(Kamal et al., 2011). Citrus fruits are a valuable source of minerals, vitamins, carbohydrates, dietary fibres, and physico-chemical features (Prasad et al., 2015; Hayat et al., 2017; Wu et al. 2018). Citrus 
belongs to the rutaceae family comprising of 140 distinct genera and 1300 species, which includes essential crops like mandarin, orange, limes, lemons, grapefruits and pummelos etc (Bora et al., 2020).

The citrus industry of Pakistan, driven by Kinnow (Citrus reticulata Blanco), is now supported by two new Kinnow strains (low seeded and seedless Kinnow) to meet the increasing domestic and international market demand. Kinnow has a vigorous, large plant with dense foliage bearing medium-large fruit with a typical orange yellowish color of rind and flesh, very juicy having rich and aromatic flavor with high nutrients (Singh, 2018). Normal Kinnow has numerous seeds, a polyembryonic, and a strong tendency to alternate bearing. Kinnow is a hybrid that originated from King and Willow Leaf cultivars and belongs to family Rutaceae (Frost, 1935). There are many problems in citrus export; most prominent of them is high seediness in citrus fruit (Mallick et al., 2017). Mandarins are rich with vitamins, natural antioxidants, physicochemical properties, and sensory attributes. Due to its richness, it is appreciated all over the world (Chopra et al., 2004; Altaf and Khan, 2008; Shireen et al., 2018).

Pakistan has taken a prominent position in the citrus industry among leading Kinnow exporting countries in the world, with an average production of 2.132 million tons, and the cultivated area is 199.9 thousand hectares (Ghani et al., 2016). Citrus is grown all over Pakistan, and more than $95 \%$ of citrus is grown in Punjab- Pakistan. Out of $95 \%$ of citrus, $70 \%$ Kinnow mandarin is grown in Punjab Provence (Khan et al., 2010). Kinnow stands first in the citrus industry of Pakistan because of wider climatic adaptation, high yield potential, a good blend of sugars and acids, consumer preference, and highest economic return (Shah, 2004). In addition to this, Kinnow is considered as a low-value export fruit because of a high number of seeds per fruits and problematic in the juice extraction and processing industry as seeds cause bitterness (Shahid et al., 2016).

The seediness in Kinnow mandarin is due to various natural factors like pollen self-incompatibility or ovule and pollen incompatibility (Altaf et al., 2004). Seedlessness is closely associated with triploidy, while spontaneous polyploidy is also found in nature (Jaskani et al., 2005; Usman et al., 2008). Crossing tetraploid and diploid cultivars can produce triploid cultivars (Krug and Bacchi, 1943). Kinnow has extreme variability because of its hybrid nature. Variability in seed number per Kinnow fruit was 0-52
(Khan, 1992; Sharma and Thind, 2005). Furthermore, Altaf and Khan (2008) found 0-3, 2-6 developed seeded branches. The seedless trait was 0-6 seeds, and the most common was 14-32 in seeded background.

Simple Sequence Repeats (SSR) markers are not available for Kinnow, which made it look into cross genera marker polymorphism and characterization of these clones (Mallick et al., 2017). So, genetic improvement within Kinnow cultivar is by selection and vegetative multiplication of natural mutant branches. Kinnow mandarin has different descriptive morphological characteristics, i.e., height, spread and canopy of plant and physico-chemical analysis of fruit like physical maturity of the fruit, total soluble solids (TSS)and acid ratio, size, and shape, juice percentage, number of seeds per fruit, peel adherence and fruits holed on the tree, etc. plants holed the fruit (Altaf et al., 2014). So, there is a dire need for the characterization of Kinnow (Agbayayo et al., 2018). The goal of this study was to characterize and compare three different strains of Kinnow mandarin (based on the high number of seeds to zero number of seeds per fruit), physico-chemical, nutritional, and proximate analysis of fruits.

\section{Material and Methods}

\section{Plant material}

The trial site for this experiment was selected at the orchard of Citrus Research Institute, Sargodha, Pakistan (Latitude $32^{\circ} 51^{\prime} \mathrm{N}$ longitude $72^{\circ} 40^{\prime} \mathrm{E}$ ). During growing season 2017 \& 2018, 'Kinnow' mandarin strains (Citrus reticulata Blanco) (seedless, less seeded and normal seeded as explained in table 1 below) plants grafted on Rough Lemon rootstock (Citrus jambhiri Lush).

Table-1: Seed characteristics of three Kinnow strains in agro-climatic conditions of Sargodha

\begin{tabular}{|l|c|}
\hline Kinnow strains & $\begin{array}{c}\text { The average number of } \\
\text { seeds/fruit }\end{array}$ \\
\hline Seedless & $0-$ seeds \\
\hline Less seeded & $2-7$ seeds \\
\hline Normal seeded & $15-27$ seeds \\
\hline
\end{tabular}

The plants spaced about $18 \mathrm{ft} . \times 18 \mathrm{ft}$, and grown in same agro-climatic conditions following recommended agronomic practices and inputs during the study period were used. Statistical analysis was done using RCBD with three treatments and three 
replications per treatment. Mature fruits were selected randomly for further physical and biochemical analyses.

\section{Physical characteristics of fruits}

A representative sample of twenty fruits was taken at the time of fruit maturity to measure the fruit size, fruit weight, juice percentage, peel thickness, and other physico-chemical parameters. Fruit diameter and peel thickness were measured by digital caliper, and fruit weight was measured by the use of the digital scale. Fruit firmness average data was collected in $\mathrm{Kg}$ by the use of a digital penetrometer; the measuring force required to penetrate the probe to a depth of $2 \mathrm{~cm}$ randomly at eight different locations in the mesocarp layer of the fruit.

TSS was measured by the help of a digital refractometer, which was provided with automation temperature correction. The $\mathrm{pH}$ of the fruit juice was expressed by the use of a bench-type digital calibrated $\mathrm{pH}$ meter at $20{ }^{\circ} \mathrm{C}$ following the Anwar et al. (2007). The amount of citric acid expressed as juice acidity was calculated by titrating the juice against a standardized solution of $0.1 \mathrm{~N} \mathrm{NaOH}$.

\section{Bio-chemical characteristics of fruits Determination of vitamin $C$ and sugars}

The amount of vitamin $\mathrm{C}$ in the juice was calculated as described by Ruck (1961). Sugar in the juice was determined as described by Hortwitz 1960. Total sugar and reducing sugars were determined through titration against Fehling solution, while non-reducing sugars were calculated by subtraction reducing sugar from total sugars.

\section{Proximate analysis}

Proximate analysis for the determination of crude fat, crude fiber, total ash, and crude protein was carried out as described in AOAC 2006. Crude fat was analyzed by Soxhlet's apparatus in which petroleum ether was used to extract the sample, which was afterward dried and weighed in a petri dish till constant reading.

The crude fiber was determined by digesting sample with $\mathrm{H}_{2} \mathrm{SO}_{4}$ and $\mathrm{NaOH}$ and incinerating the residues in a muffle furnace at elevated temperature of $550{ }^{\circ} \mathrm{C}$ till grayish-white ash, cooled weighed and calculated as below;

Crude fiber $\%=$ Weight loss on ignition $(\mathrm{g}) /$ Weight of original sample $(\mathrm{g}) \times 100$
Total ash determination was carried out by taking dried samples in a muffle furnace. The sample was added into a crucible, and the blue flame burner was used to ignite it. Then again, muffle furnace was used to reheat on a temperature of $500{ }^{\circ} \mathrm{C} \pm 5{ }^{\circ} \mathrm{C}$ for $1-2$ hours. Then weighing of the sample was done after cooling the sample in the desiccator.

For the determination of protein, the digestion mixture was prepared by $\mathrm{CuSO}_{4}+\mathrm{K}_{2} \mathrm{SO}_{4}+$ selenium oxide. This mixture was mixed with $5 \mathrm{~g}$ sample in cupped filter paper and put in Kjeldahl's flask. After adding $25 \mathrm{ml}$ of $\mathrm{H}_{2} \mathrm{SO}_{4}$ (Conc.) in the flask, contents were heated so that frothing would minimize and boiled to clean the solution thoroughly, then makeup with distilled water and cool in $100 \mathrm{ml}$ volumetric flask. $\mathrm{NaOH} 10 \mathrm{ml}$ (40\% solution) was also added to it. Free ammonia was collected in boric acid $25 \mathrm{ml}$ (4\% solution) with added indicator.

Nitrogen Percentage $=\frac{\mathrm{A}-\mathrm{Bx} 0.001}{\mathrm{~W}} \times 100 \frac{\mathrm{V}}{\mathrm{V} 1} \times 100$

$\mathrm{A}=0.1 \mathrm{~N} \mathrm{H}_{2} \mathrm{SO}_{4}$ used for sample

$\mathrm{B}=0.1 \mathrm{~N} \mathrm{H}_{2} \mathrm{SO}_{4}$ used for blank

$\mathrm{W}=$ Sample weight $(2 \mathrm{~g})$

$(\mathrm{V})=$ Volume made $(100 \mathrm{ml})$

$\left(\mathrm{V}_{1}\right)=$ Aliquot distilled $(10 \mathrm{ml})$

\section{Statistical analysis}

Randomized Complete Block Design (RCBD) was used for statistical analysis of the data. Treatments responses on fruit quality and nutritional value were statistically analyzed with software Statistix 8.1. The least significant difference (LSD) and multiple comparison tests at $P<0.05$ (Steel et al., 1997) were used to evaluate the mean comparison among the treatments. Graphical presentation of data and standard error were calculated using Sigma Plot software (SigmaPlot, 2008).

\section{Results and Discussion}

\section{Physical characteristics}

A completely randomized design ANOVA was conducted to evaluate the three different strains of Kinnow mandarin on average fruit weight, fruit size, juice, peel thickness, TSS and firmness (Table 2A). The effect of Kinnow strains on average fruit weight, $\mathrm{K}$ $(2,4) F=81.3044, p=0.0000)$, fruit size, $\mathrm{K}(2,4) F=$ $119.306, p=0.0002)$, juice, $\mathrm{K}(2,4) F=26.8536, p=$ 0.0085), peel thickness, $\mathrm{K}(2,4) F=0.21941, p=$ $0.0000)$, TSS, K $(2,4) F=1.34543, p=0.0000)$ and 
firmness, $\mathrm{K}(2,4) F=0.11231, p=0.0000)$ were significant (Table 2A). Fruit size has a vital significance for market demand. Data regarding fruit size depicted maximum fruit size $(76.0 \mathrm{~mm})$ in the case of normal seeded Kinnow, while a minimum fruit size of $63.44 \mathrm{~mm}$ was recorded in seedless Kinnow strains (Table 2B). The result of per fruit weight showed significant differences among all three Kinnow strains. Maximum weight per fruit (176.69 g) was recorded in normal seeded Kinnow, whereas the minimum fruit weight was observed $(166.28 \mathrm{~g})$ in seedless Kinnow (Table 2B). All three treatments varied in the quality of juice recovered from fruit. The results regarding juice percentage depicted significant differences among various Kinnow strains. Maximum juice $(44.29 \%)$ was found in normal seeded Kinnow, followed by less seeded Kinnow $(41.35 \%)$, and the minimum juice $(38.30 \%)$ was recorded in seedless Kinnow (Table 2B). Peel thickness was a variable trait among citrus strains. The results for peel thickness described significant differences among different Kinnow strains. Maximum peel thickness was observed in the fruit of normal seeded Kinnow $(3.01 \mathrm{~mm})$ followed by less seeded $(2.86 \mathrm{~mm})$, while minimum peel thickness $(2.48 \mathrm{~mm})$ was recorded in the seedless Kinnow fruits (Table 2B). Fruit firmness is an important criterion to assess the quality of citrus fruits. Normal seeded Kinnow showed significantly higher fruit firmness $(1.90 \mathrm{~kg})$ as compared to other treatments, and the lower fruit firmness $(1.55 \mathrm{~kg})$ was recorded in less seeded fruits (Table 2B). Kinnow has extreme variabilities in seed number per fruit and fruit quality (Altaf and Khan, 2009). Kinnow has various polyembryonic strains that grow to apomictic seeds (Altaf et al., 2004). Kinnow has low seeded/seedless fruits, and that was utilized for developing new strains (Altaf et al. 2004). The normal seeded plants were producing more fruits compared to low seeded plants, and perhaps the seed formation helps in a better fruit set (Altaf and Khan, 2009). Jaskani et al. (2002) observed that the seed number and peel thickness of diploid Kinnow trees were more than tetraploid Kinnow trees. In the present study, normal seeded Kinnow increased the peel/rind thickness, weight of fruit as compared to less seeded and seedless Kinnow fruits (Table 2B). Total soluble solids (TSS) define quality. TSS is an indicator of sweetness mostly imparted by the sugar present in the juice. The significant difference in TSS among all three contestants Kinnow strains was noticed. In the present study, significant differences of TSS $\left({ }^{\circ}\right.$ Brix) were observed among various Kinnow strains. Maximum TSS was observed in seedless Kinnow $(11.95 \%)$ followed by normal seeded Kinnow $(11.40 \%)$, while lowest TSS $(10.62 \%)$ was found in the less seeded Kinnow fruits (Table. 2B).

Table-2A. ANOVA analysis of three different strains of Kinnow mandarin on physical characteristics of fruits

\begin{tabular}{|c|c|c|c|c|c|c|c|}
\hline \multirow{2}{*}{ SOV } & \multirow{2}{*}{ df } & \multicolumn{7}{|c|}{ MS } \\
\cline { 3 - 8 } & & $\begin{array}{c}\text { Average fruit } \\
\text { weight }(\mathbf{g})\end{array}$ & $\begin{array}{c}\text { Fruit size } \\
(\mathbf{m m})\end{array}$ & Juice $(\boldsymbol{\%})$ & $\begin{array}{c}\text { Peel thickness } \\
(\mathbf{m m})\end{array}$ & TSS (\%) & $\begin{array}{c}\text { Firmness } \\
(\mathbf{k g})\end{array}$ \\
\hline Replication & 2 & 7.0019 & 0.532 & 1.0412 & 0.00338 & 0.00103 & 0.00101 \\
\hline Kinnow strains & 2 & $81.3044^{* *}$ & $119.306^{* *}$ & $26.8536^{* *}$ & $0.21941^{* *}$ & $1.34543^{* *}$ & $0.11231^{* *}$ \\
\hline Error & 4 & 0.2766 & 0.764 & 1.3663 & 0.00024 & 0.00007 & 0.00001 \\
\hline Total & 8 & \multicolumn{7}{|c|}{} \\
\hline
\end{tabular}

${ }^{* *}$ Highly Significant

Table-2B. Comparison of three different strains of Kinnow mandarin on physical characteristics of fruits

\begin{tabular}{|c|c|c|c|c|c|c|}
\hline Treatments & $\begin{array}{c}\text { Average fruit } \\
\text { weight } \mathbf{( g )}\end{array}$ & $\begin{array}{c}\text { Fruit size } \\
(\mathbf{m m})\end{array}$ & Juice $(\boldsymbol{\%})$ & $\begin{array}{c}\text { Peel thickness } \\
(\mathbf{m m})\end{array}$ & TSS (\%) & Firmness (kg) \\
\hline Normal seeded & $176.69 \mathrm{a}$ & $76.00 \mathrm{a}$ & $44.29 \mathrm{a}$ & $3.01 \mathrm{a}$ & $11.40 \mathrm{~b}$ & $1.90 \mathrm{a}$ \\
\hline Less seeded & $171.66 \mathrm{~b}$ & $68.66 \mathrm{~b}$ & $41.35 \mathrm{ab}$ & $2.86 \mathrm{~b}$ & $10.62 \mathrm{c}$ & $1.55 \mathrm{c}$ \\
\hline Seedless & $166.28 \mathrm{c}$ & $63.44 \mathrm{c}$ & $38.30 \mathrm{~b}$ & $2.48 \mathrm{c}$ & $11.95 \mathrm{a}$ & $1.59 \mathrm{~b}$ \\
\hline LSD & 1.1923 & 1.9816 & 2.6498 & 0.0354 & 0.0185 & 0.007 \\
\hline
\end{tabular}

Different letters in columns show significant difference among means of genotypes following

Tukey LSD, where $P \leq 0.05$ showed significant difference 


\section{Bio-chemical characteristics of the fruit}

A completely randomized design ANOVA was conducted to evaluate the three different strains of Kinnow mandarin on vitamin $\mathrm{C}$, beta carotene, reducing sugars, non-reducing sugars, total sugars and acidity (Table 3 ). The effect of Kinnow strains on vitamin $\mathrm{C}, \mathrm{K}(2,4) F=12.0823, p=0.0004)$, beta carotene, $\mathrm{K}(2,4) F=0.82654, p=0.0002)$, reducing sugars, $\mathrm{K}(2,4) F=0.01141, p=0.0002)$, nonreducing sugars, $\mathrm{K}(2,4) F=0.0006, p=0.0000)$, total sugars, $\mathrm{K}(2,4) F=0.09954, p=0.0000)$ and acidity, $\mathrm{K}(2,4) F=0.00760, p=0.0011)$ were significant (Table 3). Kinnow fruit is rich with Vitamin $\mathrm{C}$ and is the essential quality parameter for Kinnow fruit. Maximum vitamin C (38.5 mg/100 ml) was recorded in normal seeded Kinnow fruits, while minimum (34.80 and $35.43 \mathrm{mg} / 100 \mathrm{ml}$ ) was observed in less seeded and seedless strains, respectively (Fig. 1A). The higher $\beta$-carotene content (63.15 and 63.92 $\mu \mathrm{g} / 100 \mathrm{~g}$, respectively) were recorded in normal seeded and seedless Kinnow strains, while minimum $(62.92 \mu \mathrm{g} / 100 \mathrm{~g})$ were found in less seeded Kinnow strains (Fig. 1B). For reducing sugars, the minimum percentage $(3.35 \%)$ was acquired by seedless Kinnow fruits whereas, the maximum percentage $(3.48 \%)$ was found with less seeded Kinnow fruits (Fig. 2A). Maximum non-reducing sugar percentage (3.52\%) was attained by normal seeded Kinnow fruits followed by less seeded Kinnow fruits (3.44\%). In contrast, the seedless Kinnow fruits resulted in lowest values of non-reducing percentage (3.38\%) (Fig. 2B). While data regarding total sugars showed that minimum total sugar content $(7.50 \%)$ was recorded with less seeded Kinnow strains and the maximum amount of total sugars (7.84\%) was found in seedless Kinnow strains (Fig. 2C). Acidity is another important citrus quality parameter. The maximum juice acid content $(0.60 \%$ and $0.54 \%$, respectively) was found in normal seeded and seedless Kinnow, while minimum $(0.50 \%)$ was found in less seeded Kinnow fruits (Fig. 2D). Juice recovery is the most desirable trait by processors, which is influenced by scion/rootstock combinations (Shireen et al., 2018). Jaskani et al. (2002) reported that diploid trees had significantly higher juice percentage, TSS, and the number of developed seeds compared with tetraploids. Characteristics of seedlessness in Kinnow is because of pollen self-incompatibility, while parthenocarpy, defective ovules, and embryo abortion. It is also stated that Kinnow plants having dominant characteristics of cultivar King can easily survive in hot temperatures like Pakistan $\left(35-51^{\circ} \mathrm{C}\right.$ in summer) instead of those having dominant characteristics of Willow Leaf cultivar. Kinnow fruits have variable characteristics with regards to various parameters like seed number, fruit size, color shape, peel thickness, firmness, aroma, acidity, sweetness and juice contents etc. (Altaf and Khan, 2008). Singh (2018) reported that Kinnow cultivar has wide adaptability due to being a high yielder with abundant juice contents but has a problem of a high seed number. The high seed number is a hindrance in the adaptation of Kinnow as a table fruit, and seeds impart bitterness to juice in the processing industry. Seedless cultivars are preferred for international trade.

\section{Proximate composition}

A completely randomized design ANOVA was conducted to evaluate the three different strains of Kinnow mandarin on crude protein, crude fat, crude fiber and ash (Table 4). The effect of Kinnow strains on crude fat, $\mathrm{K}(2,4) F=0.00101 p=0.0325)$, crude fiber, $\mathrm{K}(2,4) F=0.06981, p=0.0000)$ and ash, $\mathrm{K}(2,4) F=$ $0.03303, p=0.0013)$ were significant while crude protein, $\mathrm{K}(2,4) F=0.0003, p=0.2215)$ had nonsignificant (Table 4).

Table-3. ANOVA analysis of soil applied boron on plant height, leaf area, number of bolls per plant, boll size and weight and seed cotton yield per plant of cotton cultivars

\begin{tabular}{|c|c|c|c|c|c|c|c|}
\hline \multirow{2}{*}{ SOV } & \multirow{2}{*}{ df } & \multicolumn{7}{|c|}{$\begin{array}{c}\text { Vitamin C } \\
(\mathbf{m g / 1 0 0 m L})\end{array}$} & $\begin{array}{c}\text { Beta carotene } \\
(\boldsymbol{\mu g} / \mathbf{1 0 0 g})\end{array}$ & $\begin{array}{c}\text { Reducing } \\
\text { sugars (\%) }\end{array}$ & $\begin{array}{c}\text { Non-reducing } \\
\text { sugars (\%) }\end{array}$ & $\begin{array}{c}\text { Total sugars } \\
(\%)\end{array}$ & Acidity (\%) \\
\hline Replication & 2 & 5.0833 & 0.01281 & 0.00101 & 0.00083 & 0.00381 & 0.00043 \\
\hline Kinnow strains & 2 & $12.0823^{* *}$ & $0.82654^{* *}$ & $0.01141^{* *}$ & $0.01343^{* *}$ & $0.09954^{* *}$ & $0.00760^{* *}$ \\
\hline Error & 4 & 0.1180 & 0.00518 & 0.00008 & 0.00017 & 0.00001 & 0.00013 \\
\hline Total & 8 & \multicolumn{7}{|c|}{} \\
\hline
\end{tabular}

Highly Significant 

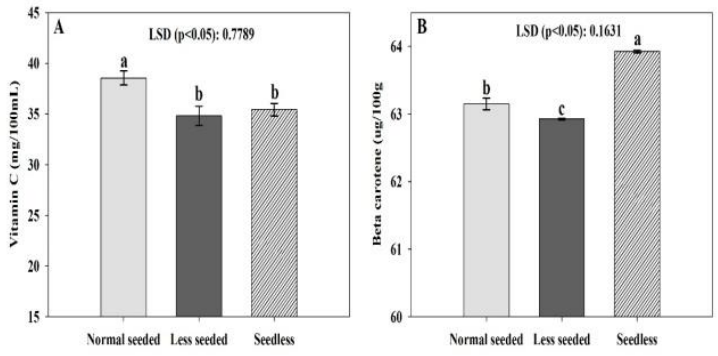

Figure-1. Comparison of three different strains of Kinnow mandarin on vitamin $C$ and beta carotene contents of fruits.

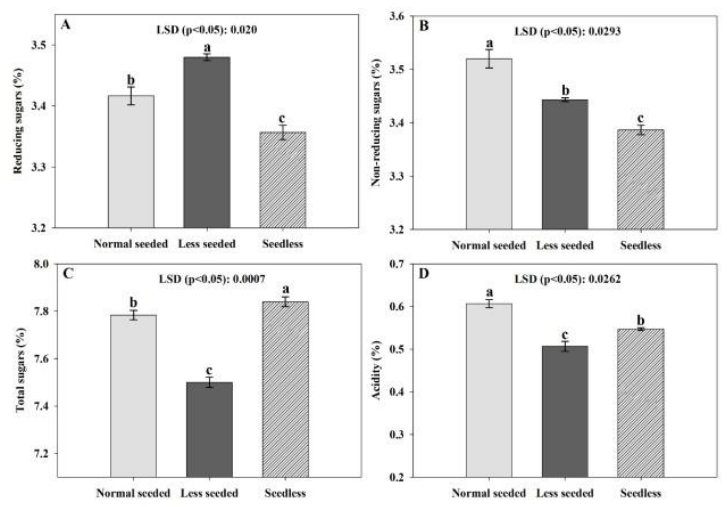

Figure-2. Comparison of three different strains of Kinnow mandarin on biochemical characteristics of fruits.

Intake of supplements in specific populations groups is recommended to meet the nutritional inadequacies but in general whole foods are preferred source of nutrients as compared to supplements (USA, 2010). Thus consumption of wholesome citrus fruit may have more nutritional benefits as compared to its juices or any sort of supplements which is evident from example of orange fruit providing better quantities of fiber and carotenoids as compared to its juice (US Department of Agriculture, Agriculture Research Service). Macronutrients including water (moisture), total carbohydrates, total lipids (fat), protein and ash are referred as proximate components of a food (USDA, 2015). Plethora of health benefits can be related to individual compounds or synergistic effects of various nutrients, proximate components and phytochemicals found in citrus fruit exerting antioxidant activities and anti- proliferative activities curing diabetes, cancer, various types of stresses improving cardiovascular health, blood pressure and cholesterol levels (Sun et al., 2002; Harats et al.,
1998; Ghanim et al., 2010). It was also reported that efficacy of antioxidant was affected through the Interaction between proteins and flavonoids (Arts et al., 2002). Data on crude protein content showed nonsignificant differences among all three various Kinnow strains (Fig. 3A). There were significant differences among different Kinnow strains with respect to crude fat. The highest crude fat $(0.180 \%)$ was detected in seedless Kinnow strain followed by less seeded $(0.163 \%)$, whereas minimum $(0.143 \%)$ crude fat was found in normal seeded Kinnow fruits (Fig 3B). Citrus fruit contain minimal quantities of fat and cholesterol contrary to energy-dense foods causing obesity and cardiovascular disorders. Consumption of citrus fruit aids in controlling the effects of diabetes due to having relatively low glycemic index. Although a difference was found in fat percentage among three strains but due to minimal quantities the difference is not significant for nutritionists. The maximum percentage of crude fiber $(2.60 \%)$ was found in seedless Kinnow fruits, and a minimum percentage $(2.31 \%)$ was observed in normal seeded Kinnow fruits (Fig. 3C). Dietary fiber is not digested and absorbed in body mainly consists on edible carbohydrates and lignin found in plants while fiber in citrus fruit is predominantly comprise on pectin $(65-70 \%)$ which is a soluble fiber. Fibers reduce absorption of bile acids, fat, glucose and cholesterol reducing risk of cardiovascular disorders promoting satiety, laxation and healthy intestinal fermentation (Brown et al., 1999; Dikeman and Fahey, 2006; Economos and Clay, 2012).

Table-4. ANOVA analysis of soil applied boron on plant height, leaf area, number of bolls per plant, boll size and weight and seed cotton yield per plant of cotton cultivars

\begin{tabular}{|l|c|c|c|c|c|}
\hline \multirow{2}{*}{ SOV } & & \multicolumn{5}{|c|}{ Mf } & $\begin{array}{c}\text { Crude } \\
\text { protein } \\
(\%)\end{array}$ & $\begin{array}{c}\text { Crude } \\
\text { fat (\%) }\end{array}$ & $\begin{array}{c}\text { Crude } \\
\text { fiber (\%) }\end{array}$ & Ash (\%) \\
\hline Replication & 2 & 0.00003 & 0.00014 & 0.00101 & 0.00023 \\
\hline $\begin{array}{l}\text { Kinnow } \\
\text { strains }\end{array}$ & 2 & $0.0003^{\mathrm{NS}}$ & $0.00101^{*}$ & $0.06981^{* *}$ & $0.03303^{* *}$ \\
\hline Error & 4 & 0.0001 & 0.00011 & 0.00003 & 0.00062 \\
\hline Total & 8 & \multicolumn{5}{|c|}{} \\
\hline
\end{tabular}

Highly Significant NS = Non-significant

Significant percentage of crude fiber found in seedless Kinnow fruit is an optimistic development for health conscious consumers. For ash, minimum 
ash percentage was acquired by less seeded (1.82\%) and normal seeded Kinnow (1.88\%) whereas maximum ash percentage was found in seedless Kinnow fruits (2.03\%) (Fig. 3D).

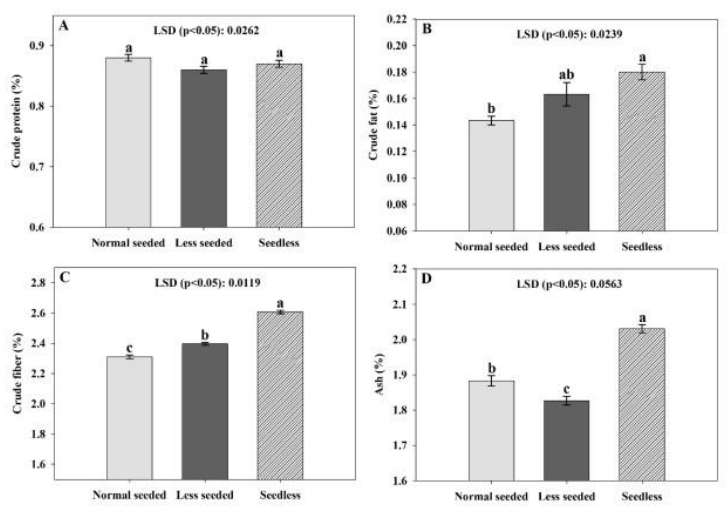

Figure-3. Comparison of three different strains of Kinnow mandarin on proximate analysis of fruits

\section{Conclusion}

This study was undertaken to evaluate two new strains, i.e., low seeded and seedless Kinnow with normal seeded Kinnow for various biochemical quality parameters. Results indicated that two new strains did not differ much for fruit quality characteristics and nutritional value. While seedless and less seeded can add to varietal diversification to the citrus industry of Pakistan and can accelerate the fruit demand in local as well as the nutritional market as a table fruit and for processing as well.

\section{Acknowledgment}

The authors of this manuscript would like to thank the Punjab Agriculture Research Board (PARB), Lahore for their financial support for this project.

Disclaimer: None.

Conflict of Interest: None.

Source of Funding: This project was finically supported by Punjab Agriculture Research Board (PARB), Lahore, Pakistan

\section{References}

Agbayayo OO, John OO, AS LB, Noa AP and Ikechi AE, 2018. Comparative studies of phytochemistry, proximate, mineral and vitamin compositions of Citrus tangerina and Citrus sinensis crude fruit peel extracts. Acta Sci. Pharm. Sci. 2: 22-26.

Altaf $\mathrm{N}$ and Khan AR, 2008. Variation within kinnow (Citrus reticulata) and rough lemon (Citrus jambheri). Pak. J. Bot. 40: 589-598.

Altaf N and Khan AR, 2009. Growth and development of low seeded kinnow mandarin fruits in dense plantation. J. Agric. Sci. Technol. 11: 191-198.

Altaf N, Iqbal MM and Khan EU, 2004. Towards a seedless cultivar of Kinnow mandarin VII. Natural and induced variability. Pak. J. Bot. 36: 93-102.

Altaf S, Khan MM, Jaskani MJ, Khan IA, Usman M, Sadia B, Awan FS, Ali A and Khan AI, 2014. Morphogenetic characterization of seeded and seedless varieties of Kinnow Mandarin (Citrus reticulata Blanco). Aust. J. Crop Sci. 8: 1542-1549.

Anwar F, Latif S, Przybylski R, Sultana B and Ashraf M, 2007. Chemical composition and antioxidant activity of seeds of different cultivars of mungbean. J. Food Sci. 72: 503510.

AOAC (Official Methods of Analytical Chemist), 2006. Washington DC, USA, p. 42.

Arts MJ, Haenen GR, Wilms LC, Beetstra SA, Heijnen CG and Voss HP, 2002. Interactions between flavonoids and proteins: Effect on the total antioxidant capacity. J. Agri. Food Chem. 50: 1184-1187.

Bora $\mathrm{H}$, Kamle $\mathrm{M}$, Mahato DK, Tiwari $\mathrm{P}$ and Kumar P, 2020. Citrus Essential Oils (CEOs) and Their Applications in Food: An Overview. Plants. 9: 357.

Brown L, Rosner B, Willett WW and Sacks FM, 1999. Cholesterol-lowering effects of dietary fiber: A meta-analysis. Am. J. Clin. Nutr. 69: 30-42.

Chopra S, Kudos SKA, Oberoi HS, Baboo B, Ahmad KUM and Kaur J, 2004. Performance evaluation of evaporative cooled room for storage of kinnow mandarin. J. Food Sci. Technol. 41: 573-577.

Dikeman CL and Fahey GC, 2006. Viscosity as related to dietary fiber: A review. Crit. Rev. Food Sci. 46: 649-663.

Economos C and Clay W, 2012. Nutritional and health benefits of citrus fruits. Food and 
Agriculture Organization. Available online: ftp://ftp.fao.org/docrep/fao/X2650T/X2650t03.

Frost H, 1935. Four new citrus varieties: the Kara, Kinnow, and Wilking mandarins and the Trovita orange. Univ California, Agric. Exp. Stn. Bull. 4.

Ghani A, Ikram M, Hussain M, Ahmad I and Iftikhar M, 2016. Comparative Analysis of Ascorbic Acid Concentration in Citrus Reticulata (Kinnow) Collected From Different Tehsils of Sargodha. 6: 43-47.

Ghanim H, Sia CL, Upadhyay M, Korzeniewski K, Viswanathan P, Abuaysheh S, Mohanty P and Dandona P, 2010. Orange juice neutralizes the proinflammatory effect of a high-fat, highcarbohydrate meal and prevents endotoxin increase and Toll-like receptor expression. Am. J. Clin. Nutr. 91: 940-949.

Harats D, Chevion S, Nahir M, Norman Y, Sagee $\mathrm{O}$ and Berry EM, 1998. Citrus fruit supplementation reduces lipoprotein oxidation in young men ingesting a diet high in saturated fat: Presumptive evidence for an interaction between vitamins $\mathrm{C}$ and $\mathrm{E}$ in vivo. Am. J. Clin. Nutr. 67: 240-245.

Hayat F, Khan MN, Zafar SA, Balal RM, Nawaz MA, Malik AU and Saleem BA, 2017. Surface coating and modified atmosphere packaging enhances storage life and quality of 'Kaghzi lime'. 1151-1160.

Hortwitz W, 1960. Official and tentative methods of analysis. Assoc Off Agric Chem Washington, DC. Ed. 9: 320-341.

Jaskani MJ, Khan MM and Khan IA, 2002. Growth , morphology and fruit comparison of diploid and tetraploid kinnow mandarin. Pak. J. Agric. Sci. 39: 126-128.

Jaskani MJ, Kwon SW and Kim DH, 2005. Comparative study on vegetative, reproductive and qualitative traits of seven diploid and tetraploid watermelon lines. Euphytica. 145: 259-268.

Kamal GF, Anwar A, Hussain NS and Ashraf M, 2011. Yield and chemical composition of Citrus essential oils as affected by drying pretreatment of peels. Int. Food Res. J. 18: 1275

Khan IA, 1992. "The Kinnow Culture." In Proceedings of the first international seminar on citriculture in Pakistan, pp. 2-5.
Khan MN, Nawaz MA, Ahmad W, Afzal M, Malik AU and Saleem BA, 2010. Evaluation of some exotic cultivars of sweet orange in Punjab, Pakistan. Int. J. Agric. Biol. 12: 729-733.

Krug C and Bacchi O, 1943. Triploid varieties of Citrus. J. Hered. 34: 277-283.

Mallick M, Bharadwaj C, Srivastav M, Sharma N and Awasthi OP, 2017. Molecular characterization of Kinnow mandarin clones and mutants using cross genera SSR markers. Ind. J. Biotechnol. 16: 244-249.

Prasad H, Thakur M, Gupta AK and Prasad D, 2015. Effect of foliar application of 2, 4-D, urea and zinc sulphate on fruit drop, yield and fruit quality of Kinnow mandarin. Int. J. Bioresour. Stress Manage. 6: 619-622.

Ruck JA, 1961. Chemical method for fruit and vegetable products. Res. Sta. Summerland; Res. Branch, Canada. Dept. of Agric. No. 1154.

Shah MA, 2004. "Citrus Cultivation in NWFP." In Proceedings of the $1^{\text {st }}$ International conference on citriculture, pp. 36-39.

Shahid AK, Abdus S and Roshan Z, 2016. Development of sparse-seeded mutant kinnow (Citrus reticulata Blanco) through budwood irradiation. Afr. J. Biotechnol. 10: 1456214565.

Sharma JN and Thind SK, 2005. An opproach for the establishment of seedlessness in Kinnow mandarin. Ind. J. Hortic. 62: 8-11.

Shireen F, Jaskani MJ, Nawaz MA and Hayat F, 2018. Exogenous application of naphthalene acetic acid improves fruit size and quality of kinnow mandarin (Citrus reticulata) through regulating fruit load. J. Anim. Plant Sci. 28(4): 1080-1084.

SigmaPlot (r)-Scientific Data Analysis and Graphing Software. Systat Software INC. 2008.

Singh SK, 2018. Characterization of Kinnow mandarin fruit juice stored under incubator. Ann. Bio. 31: 126-129.

Steel RGD, Torrie JH and Dickey DA, 1997. Principles and procedures of statistics: a biometrical approach. 3rd Ed McGraw Hill Book Co Inc New York, USA.

Sun J, Chu YF, Wu X and Liu RH, 2002. Antioxidant and antiproliferative activities of common fruits. J. Agric. Food Chem. 50: 74497454. 
USA, 2010. Dietary Guidelines for Americans, $7^{\text {th }}$ ed. U.S. Government Printing Office, Washington DC, USA.

USDA, 2015. Composition of Foods Raw, Processed, Prepared USDA. National Nutrient Database for Standard Reference, Release 28 Documentation and User Guide. Available online: http://www.ars.usda.gov/nutrientdata

Usman M, Fatima B, Gillani KA, Khan MS and Khan MM, 2008. Exploitation of potential target tissues to develop polyploids in citrus. Pak. J. Bot. 40: 1755-1766.

Wu GA, Terol J, Ibanez V, López-García A, PérezRomán E, Borredá C, Domingo C, Tadeo FR, Carbonell-Caballero J, Alonso $\mathrm{R}$ and Curk F, 2018. Genomics of the origin and evolution of Citrus. Nature. 554: 311-316.

\section{Contribution of Authors}

Khan MN: Conceived idea, manuscript final reading and approval

Asim M: Designed research methodology, data collection, analysis and manuscript writing Mehmood A: Manuscript final reading and approval Haq EU: Data collection and analysis Ashraf T: Literature review and data interpretation Anjum N: Literature review and manuscript writing Hayat F: Statistical analysis and manuscript writing Salik R: Literature review and manuscript writing Jamil A: Data collection and analysis Qamar R: Data interpretation, statistical analysis, manuscript final reading and approval 